\title{
CHAGAS' DISEASE: AN ALGORITHM FOR DONOR SCREENING AND POSITIVE DONOR COUNSELING
}

\author{
Nelson Hamerschlak, Jacyr Pasternak, Vicente Amato Neto, Márcia B. de \\ Carvalho, Carmen S. Guerra , Antonio L. Coscina, Orlando C. Ferreira, \\ Jacob Rosenblit and Leonel N. Szterling
}

\begin{abstract}
Classical serological screening assays for Chagas' disease are time consuming and subjective. The objective of the present work is to evaluate the enzyme immuno-assay (ELISA) methodology and to propose an algorithm for blood banks to be applied to Chagas' disease. Seven thousand, nine hundred and ninety nine blood donor samples were screened by both reverse passive bemagglutination (RPHA) and indirect immunofluorescence assay (IFA). Samples reactive on RPHA and/or IFA were submitted to supplementary RPHA, IFA and complement fixation (CFA) tests. This strategy allowed us to create a panel of 60 samples to evaluate the ELISA methodology from 3 different manufacturers. The sensitivity of the screening by IFA and the 3 different ELISA's was 100\%. The specificity was better on ELISA methodology. For Chagas disease, ELISA seems to be the best test for blood donor screening, because it showed high sensitivity and specificity, it is not subjective and can be automated. Therefore, it was possible to propose an algorithm to screen samples and confirm donor results at the blood bank.

Key-words: Chagas' disease. Chagas' serology. Blood donor screening. Enzyme immuno assay (ELISA).
\end{abstract}

Chagas' disease is a major concern for blood transfusion in Latin America. There are 18 endemic countries and an overall prevalence of 16-18 million people with Chagas' disease was estimated. In Brazil, the endemic area comprises more than $3.500 .000 \mathrm{~km}^{2}$ involving 17 states and 2.400 cities in the Northeast, Southeast, South and Central West regions. Vector control program has been improved but the migration of infected people from endemic areas to urban centers is very hight. The number of transfusions in Brazil is presently reaching 5 to 6 million per year ${ }^{4}$. Therefore, the deferral of blood donors at risk for the infection and laboratory tests are reasonable ways to prevent transfusion transmitted Chagas' disease. Methods designed to detect Trypanosoma cruzi antigens or the whole parasite have low sensitivity because parasitemia

Serviço de Hemoterapia e Laboratório de Patologia Clínica do Hospital Israelita Albert Einstein and Divisão de Doenças Infecciosas e Parasitárias do Hospital das Clínicas da Faculdade de Medicina da Universidade de São Paulo, São Paulo, SP, Brasil. Address to: Dr. Nelson Hamerschlak. Hospital Albert Einstein/Hemotherapy Service. Av. Albert Einstein $627,4^{\circ}$ andar, 05651-901 São Paulo, SP, .Brazil. Tel: (011) 845-0444. Fax: (011) 845-0446

Recebido para publicação em 06/05/96. is low or non-existent in chronically infected individuals. The most useful assay for routine screening of Chagas' disease is the detection of antibody against purified antigens or protein extracts from in vitro cultured Trypanosoma cruzi. Classical assays such as complement fixation (CFA) described by Guerreiro and Machado in 19138, indirect immunofluorescence assay (IFA), used since $1960^{6}$ and reverse passive hemagglutination (RPHA) used since 197010 are time consuming and prone to subjective interpretation, but are still common in blood donor screening. Recently, ELISA (enzyme linked immunosorbent assay) tests for Chagas' disease are being marketed by different manufacturers. The distribution of Chagas' disease in Brazil is geographically heterogeneous. Endemic areas of active insect mediated transmission of Chagas' disease have decreased as a result of effective public health measures4. Consequently, blood transfusion became more important as a way of transmission of Chagas' disease in Brazil, because of blood donation by chronically infected individuals not showing overt disease. Blood donor screening for Chagas' disease is mandatory throughout the country, and every donation should be subject to a minimum of two tests, using different methods. We studied samples 
Hamerschlak N, Pasternak J, Amato Neto V, Carvalbo MB, Guerra CS, Coscina AL, Ferreira OC, Rosenblit J, Szterling LN. Chagas' disease: an algorithm for donor screening and positive donor counselling. Revista da Sociedade Brasileira de Medicina Tropical 30:205-209, mai-jun, 1997.

from 7,999 donors which had been screened by both, RPHA and indirect immunofluorescence assays IFA. Based on this observation, on the comparison with ELISA results and on simple epidemiological information we propose a simple algorithm for Chagas' disease screening and counseling of blood donors.

\section{MATERIAL AND METHODS}

This study was carried out at the Blood Bank of the Hospital Albert Einstein, a nonprofit private institution in the city of São Paulo. All candidates for blood donation were interviewed. The candidates were deferred as blood donors if they had any risk factors for Chagas' disease. Risk factors for Chagas' disease were considered positive when: a) the donor recognized the insect that transmits the disease (the donor was shown photographs of different species of the triatomidae), b) had lived in endemic areas in homes infested by the triatomidae, or c) had received blood transfusions.

A total of 7,999 blood donors were studied and screened by RPHA assay (Biolab, Sao Paulo, SP, Brazil) and by IFA (Biolab, São Paulo, SP, Brazil). Serum dilutions of $1 / 40$ for RPHA and $1 / 20$ for IFA were used for sample screening. If both reactions were negative the donor was considered negative for Chagas' disease and blood released for transfusion. If one test was positive or doubtful, it was repeated in duplicate. Samples which were repeated reactive were subjected to CFA, IFA and RPHA, performed in another laboratory with different reagents and by different personnel, as supplementary tests for diagnostic purposes.

This strategy allowed us to characterize a panel of 60 samples, 43 of which had repeatedly positive results in at least one of the screening tests. The remaining 17 samples showed negative results in all screening and supplementary tests. All samples from this panel were submitted to 3 different ELISAs (Abbott, Chicago, IL, USA; Biolab-Merieux, Rio de Janeiro, RJ, Brazil; Gull Laboratories, Salt Lake City, UT, USA).
There are no gold standards for the laboratory diagnosis of Chagas' disease. In order to estimate assay sensitivity and specificity, we defined a criteria to evaluate the ELISA tests which we called Combined Assay Performance (CAP). CAP was considered positive if confirmatory immunofluorescence was positive and at least 2 of the 3 ELISA assays were positive.

\section{RESULTS}

We screened 7,999 blood samples for Chagas' disease using RPHA and IFA. Initial reactivity (IR) on RPHA and/or IFA discarded 205 blood units (2.56\%). After supplementary tests, 45 samples were positive, giving a prevalence for Chagas' disease of $0.56 \%$ (Table 1 ). Based on these figures only $22 \%$ of IR samples were confirmed positive, thus illustrating the poor specificity of the screening assays. The panel for ELISA analysis (Table 2) was created among these reactive and non reactive samples.

Table 1 - Distribution of reactive screening and supplementary tests for Chagas' disease. Total number of donor $=7999$.

\begin{tabular}{lrr} 
for Chagas' disease. Total number of donor $=7999$. & \\
\hline Reactive tests & № & $\%$ \\
Supplementary reactive tests & 205 & 2.56 \\
Supplementary reactive/reactive tests & - & 0.56 \\
\hline
\end{tabular}

Other aspects that we have evaluated are that IFA assay is not ideal for blood donor screening because it is subjective and time consuming. Therefore, we have evaluated the performance of the ELISA assays available on the market aiming the substitution of the IFA for one of the ELISAs.

Table 2 shows ELISAs compared to screening tests (IFA and RPHA) and CAP. It is clear that when 2 screening tests are positive there is complete agreement between ELISAs and CAP.

If screening is positive by immunofluorescence alone, then the confirmation rate by CAP is $10 \%$. If both screening tests are negative, CAP is $100 \%$ negative.

Table 2 - Screening tests (IFA and RPHA), ELISA's and CAP. This table show that ELISA's and IFA have the same sensitivity.

\begin{tabular}{|c|c|c|c|c|c|c|c|c|c|c|}
\hline \multirow[t]{2}{*}{ IFA } & \multirow[t]{2}{*}{ RPHA } & \multirow[t]{2}{*}{ № } & \multicolumn{2}{|c|}{ ELISA 1} & \multicolumn{2}{|c|}{ ELISA 2} & \multicolumn{2}{|c|}{ ELISA 3} & \multicolumn{2}{|c|}{ CAP } \\
\hline & & & № & $\%$ & № & $\%$ & № & $\%$ & № & $\%$ \\
\hline+ & + & 20 & 20 & 100 & 20 & 100 & 20 & 100 & 20 & 100 \\
\hline+ & - & 19 & 4 & 21 & 7 & 37 & 2 & 11 & 2 & 11 \\
\hline - & + & 4 & 0 & - & 0 & - & 1 & - & 0 & - \\
\hline - & - & 17 & 0 & - & 0 & - & 0 & - & 0 & - \\
\hline
\end{tabular}


Hamerschlak N, Pasternak J, Amato Neto V, Carvalbo MB, Guerra CS, Coscina AL, Ferreira OC, Rosenblit J, Szterling LN. Chagas' disease: an algorithm for donor screening and positive donor counselling. Revista da Sociedade Brasileira de Medicina Tropical 30:205-209, mai-jun, 1997.

Using CAP as the gold standard the sensitivity and specificity of the screening by RPHA, IFA and the 3 different ELISAs is showed in Table 3.

\begin{tabular}{|c|c|c|}
\hline & Sensitivity (\%) & Specificity (\%) \\
\hline$\overline{\mathrm{RPHA}}$ & 91 & 89 \\
\hline IFA & 100 & 56 \\
\hline ELISA 1 & 100 & 95 \\
\hline ELISA 2 & 100 & 87 \\
\hline ELISA 3 & 100 & 97 \\
\hline
\end{tabular}

\section{DISCUSSION}

For the blood supply safety, sensitivity is more important than specificity. In our series, IFA and ELISA had the same sensitivity when CAP was used as a gold standard. ELISA is easier to perform and quality can be better controlled in the blood banking routine. Risk factor alone is a reasonable way for preventing Chagas' disease to be transmitted by transfusion, and it is actually what has been used in the US and other areas of low prevalence of positive



Figure 1 - Proposed algorithm for screening and couselling of Chagas' disease in Blood Banking. 
Hamerschlak N, Pasternak J, Amato Neto V, Carvalbo MB, Guerra CS, Coscina AL, Ferreira OC, Rosenblit J, Szterling LN. Chagas' disease: an algorithm for donor screening and positive donor counselling. Revista da Sociedade Brasileira de Medicina Tropical 30:205-209, mai-jun, 1997.

donors. In Brazil, this would cause the loss of many donors. Mainly because endemic areas are heterogeneous with reference to individuals at risk of active insect transmission, assuming that the whole population of a specific endemic region is potentially infected, we would be causing deferral of too many blood donors. Nevertheless, when there is a strong risk factor, for instance when the donor knows and declares that he/she was bitten by the "kissing bug", he/she is deferred and not even tested.

Screening assays with high sensitivity usually generates many false positive results which is also a problem for blood banks. For instance, in the largest blood bank of Brazil, Fundação Hemocentro, São Paulo, 3.4\% of all units are discarded because of one positive screening test for Chagas' disease 2 . In our institution $2.6 \%$ of all units are also discarded because of one positive screening test, and only 1 out of 5 of those units are considered true positive. The economic loss and problems created by anguish and fear in donors are considerable. Our results show that interview and clinical assessment are insufficient for screening Chagas infection. RPHA as a screening was not as sensitive as ELISAs and IFA. ELISA and IFA have the same sensitivity. The IFA specificity in the screening is lower then the ELISA's.

Chagas' disease is beginning to become a problem in other countries: in the United States, cases of transmission have been found 7913 and in some areas, like Florida and California, there is a sizeable minority of individuals born in endemic areas, potentially capable of transmitting the disease if they donate blood. The methodology applied for screening Chagas' disease in blood donors has to have some parameters that include: simplicity, specificity, sensitivity, low cost and performance by automated laboratory equipment. Prevention of transfusion-transmitted Chagas' disease does not mean only serological testing. In highly endemic areas, some blood banks in Brazil add crystal violet to all blood units, and this method is $100 \%$ effective, very cheap, and with minimal side effects 11 . Crystal violet gives a violet hue to the blood, and not all physicians and patients find it acceptable; this is not the method we would recommend to be used in non-endemic areas as prevention of Chagas' disease in blood transfusion. The epidemiological data is also useful in low prevalence areas as a criterium to evaluate donors: however, active transmission areas of Chagas' disease are changing and the information related to old epidemiological areas are not easy to be obtained. Many individuals, now living in the US, arrived in the country decades ago, when the transmission area was much larger. São Paulo State does not have insect transmission of Chagas' disease anymore3. Therefore, we propose an algorithm (Figure 1) as a routine for prevention of Chagas' disease through blood transfusion. However, the definitive solution of Chagas' disease screening is the development of a gold standard. Polymerase chain reaction (PCR), although not suitable as a screening test at the moment is a possible candidate to be used in the future1.

\section{RESUMO}

Os testes sorológicos clássicos utilizados na triagem de doadores de sangue são trabalhosos $e$ subjetivos. O objetivo do presente trabalbo é o de avaliar a metodologia imuno-enzimática (ELISA) e propor um algorítmo para doença de Chagas em bancos de sangue. Foram estudados 7999 doadores de sangue e/ou componentes cujas amostras foram testadas com o objetivo de tria-las sorologicamente para doença de Chagas utilizando hemaglutinação passiva reversa (RPHA) e imunofluorescência indireta (IFA). As amostras reativas em pelo menos uma destas metodologias, foram retestadas com reativos diferentes por RPHA, IFA e fixação de complemento (CFA). Esta estratégia nos permitiu criar um painel de 60 amostras com as quais tornouse possível a avaliação do método imunoenzimático (ELISA). A sensibilidade da triagem dos doadores pelos métodos ELISA e IFA foi de 100\%. A especificidade fo $i$ melhor para a metodologia imunoenzimática. O teste ELISA parece ser o ideal para triagem em bancos de sangue pois é altamente sensível, específico, não é subjetivo e pode ser automatizado. Desta forma, torna-se possivel a formulação de um algorítimo a ser utilizado na triagem sorológica e confirmação de resultados em doadores de bancos de sangue.

Palavras-chaves: Doença de Chagas. Sorologia da doença de Chagas. Triagem de doadores de sangue. Método imunoenzimático (ELISA).

\section{REFERENCES}

1. Araujo FG. Perspectives for confirmatory tests in: Wendel S, Brener Z, Camargo ME, Rassi A (eds). Chagas Disease (American Trypanosomiasis), Its impact on transfusion and clinical Medicine. ISBT, São Paulo, p 219-223, 1992. 
2. Carvalho MR, Krieger MA, Almeida E, Oelemann W, Shikanai-Yassuda MA, Ferreira AW, Pereira JB, Saez-Alquézar A, Dorlhiac-Llacer PE, Chamone DF, Goldenberg S. Chagas' disease diagnosis: evaluation of several tests in blood bank screening.Transfusion 33: 830-834, 1993.

3. Dias JCP. Control of Chagas disease in Brazil. Parasitology Today 3: 336-341, 1987.

4. Dias JCP . Epidemiology of Chagas' disease in: Wendel S, Brener Z, Camargo ME, Rassi A (eds). Chagas Disease (American Trypanosomiasis): Its impact on transfusion and clinical medicine. ISBT, São Paulo, p. 49-80, 1992.

5. Ferreira AW, Belem ZR, Moura MEG, Camargo ME. Aspectos da padronização de testes sorológicos para doença de Chagas. Um teste imunoenzimático para a triagem de sangue. Revista do Instituto de Medicina Tropica de São Paulo 33:123-128, 1991.

6. Fife $\mathrm{Jr} \mathrm{EH}$, Mushel LH. Fluorescent antibody technique for serodiagnosis of Trypanosoma cruzi. Proceedings of the Society for Experimental Biology and Medicine 101: 540-543, 1959.

7. Giant IH, Gold JWM, Wittner M. Transfusion associated to acute Chagas disease acquired in the United States. Annals of Internal Medicine 11: 849-851, 1989.

8. Guerreiro C, Machado A. Da reação de Bordet e Gengou na moléstia de Carlos Chagas como elemento diagnóstico. Brasil Médico 27-225-226, 1913.

9. Hagar JM, Rahimtoola SH. Chagas heart disease in the United States. New England Journal of Medicine 325: 763-766, 1991.

10. Knierim F, Rubinstein P. The detection of Chagas disease .Vox Sanguinis 18: 280-286, 1970.

11. Nussensweig V, Sontag R, Biancalana A. Ação de corantes trifenilmetanicos sobre o Trypanosoma cruzi in vitro. Emprego da violeta de genciana na profilaxia da transmissåo da moléstia de Chagas por transfusão de sangue. O Hospital 44: 731-744, 1953.

12. Voller A, Draper C, Bidwell DE, Bartlett A.A microplate enzyme-linked immunosorbent assay (ELISA) for Chagas disease. Lancet 1:426-429, 1975.

13. Wendel S, Gonzaga AL. Chagas disease and blood transfusion:A new world problem? Vox Sanguinis 63:1-12, 1992. 